\title{
APPLICATION OF A BIOPREPARATION WITH CULTURES OF EFFECTIVE MICROORGANISMS TO THE PROCESSING OF WASTEWATER SLUDGE ON A SEMI-INDUSTRIAL SCALE
}

\begin{abstract}
The conditions have been examined under which selected groups of microorganisms might be applied to prevent or significantly reduce the generation of odour from the processing and storage of the wastewater sludge. A series of experiments were conducted on a semi-industrial scale, using effective microorganisms (EM) activated in molasses solutions. The analysis of the results showed that the biopreparation modified the biochemical processes most effectively when a structural material was added to the sludge. The processing of the sludge with added EM caused a 20-26\% reduction in odour emissions, despite an increase in ammonia emissions. It also led to a higher dry matter content, which indicates a better dewatering ability of the sludge treated with EM. It can be concluded that the treatment of wastewater sludge with EM and the structural material when the $\mathrm{C} / \mathrm{N}$ ratio is low can help achieve the desired goal of reducing the odour emission.
\end{abstract}

\section{INTRODUCTION}

Sewage sludge may represent the most problematic aspect of wastewater treatment due to its very watery nature (moisture content reaching 99\%) as well as high content of easily decomposable organic substances whose rapid degradation generates unpleasant odours. Therefore, the efficient operation of a wastewater treatment plant requires appropriate processing of sewage sludge, aimed at the overall stabilization of the sludge, in order to minimize the volume of odour and maximize the mineralisation of organic compounds.

When it comes to unpleasant smells, municipal companies (primarily those operating wastewater treatment plants) constitute the largest group of socially disruptive entities. An obnoxious odour of substances is mainly exposed in the course of utilisation processes and as screenings, sand, and sludge are stored. They reflect the biochemical

${ }^{1}$ Rzeszów University of Technology, Aleja Powstańców Warszawy 12, 35-959 Rzeszów, Poland, corresponding author M. Grabas, e-mail: grabas@prz.edu.pl 
processes that take place in technological devices and storage yards as well as during the transport of the sewage sludge to the place of its final utilisation. More specifically, the processing of sewage sludge yields large quantities of odorants related with its stabilisation, dewatering processes, and storage [1-4]. The sludge storage zone is characterised by the highest incidence of odours.

The processes of biochemical decomposition, affecting organic compounds in sewage sludge and other wastes like carbohydrates, proteins, and fats contributes to the formation of intermediate products, characterised by a smell that is very unpleasant for the environment $[5,6]$. The impurities creating odours are mainly organic compounds with aldehyde $(-\mathrm{CHO})$, carbonyl $(=\mathrm{CO})$, hydroxyl $(-\mathrm{OH})$, hydrosulphide $(-\mathrm{SH})$, and amino $\left(-\mathrm{NH}_{2}\right.$, $=\mathrm{NH})$ groups. Odour-nuisance gases are in turn a mixture of: volatile organic compounds (mercaptans, alkyl sulphides and polysulphides, indole, aliphatic amines, aldehydes, ketones, and fatty acids) and inorganic compounds (ammonia, hydrogen sulphide) $[2,5,6]$.

In order to eliminate or reduce the odour from wastewater treatment plants, various actions have been undertaken to develop deodorisation techniques that could be categorised as biological or physicochemical. On the biological side, modifications to the way in which sewage sludge is processed may yield significant reductions in the intensity of odour. These may be primarily achieved through the augmentation of sludge with microorganisms that alter biochemical processes. In this way, noticeable reductions in the number of products with noxious odours generated can be achieved $[5,7]$.

In the context of the work described here, the EM-Bio biopreparation was used with the above aim in mind [8]. Biopreparation alters the composition of the sewage sludge microflora, thereby changing the relative concentration of various organic compounds and, as a consequence, reducing the number of odours released $[9,10]$.

Specifically, the work described in this paper sought to determine the conditions, under which the application of selected groups of microorganisms might prevent or significantly reduce the generation of odours during the utilization and storage of wastewater sludge.

\section{EXPERIMENTAL}

Methods. The biopreparation with cultures of effective microorganisms (EM), marketed under the trade name EM-Bio, was used in the experiment. This mixture of microorganisms (acid milk bacteria, photosynthetic bacteria, yeast, and actinomycetes) is activated in a molasses solution. The biopreparation was activated according to the manufacturer's recommendation. The dose of the activated biopreparation applied to the sludge was $8 \mathrm{~cm}^{3} / \mathrm{kg}$ on a dry matter $(\mathrm{dm})$ basis.

The sludge used in the experiment came from a small municipal wastewater treatment plant. This was the return sludge that was thickened in a gravity thickener, condi- 
tioned using polyelectrolyte, and dewatered. It was mixed with the additions and biopreparation, using a mechanical stirrer, and placed in an open outdoor container (Fig. 1). Four containers with 100-137 kg of sludge were prepared and underwent experimental processing in line with the following scheme:

- check test (1, control test),

- test with EM biopreparation, test 2,

- test with EM biopreparation and bark compost (20.3\% fresh mass), test 3,

- test with EM biopreparation and calcium oxide $(\mathrm{CaO}-0.04 \mathrm{~g} / \mathrm{kg} \mathrm{dm})$, test 4 .

The processing of the sludge lasted 117 days, from May 15 to September 9, during which the average day temperatures were above $12{ }^{\circ} \mathrm{C}$. Each container was initially mixed at 7-day intervals during the first month of the experiment and later, after sampling in the next phases of the experiment.

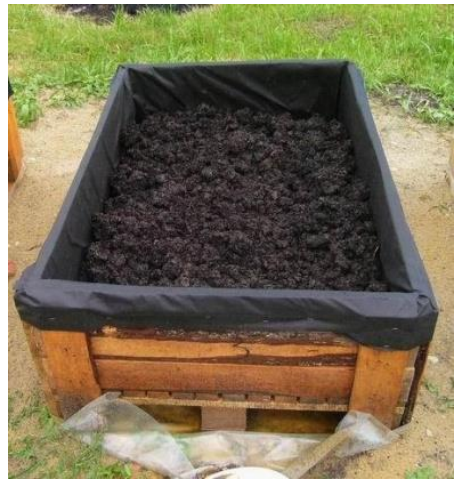

Fig. 1. Container with sludge

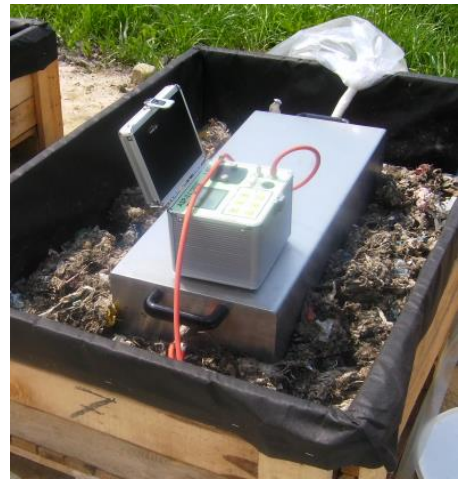

Fig. 2. Device for air sampling from the area sources

Samples of the wastewater sludge were obtained, using a previously disinfected sampler for soil sampling. The samples were taken in accordance with the Polish Norm PN-R-04031:1997. The following parameters were analysed: temperature, reaction (PN-Z-15011-3:2001), redox potential (PN-ISO 11271:2007), fresh mass and dry mass (PN-Z-15011-3:2001, using the lyophilisation process), volatiles in dry matter (PN-Z -15011-3:2001), total nitrogen and total organic carbon (PN-ISO-13878, PN-ISO 10694).

Total organic carbon (TOC) was measured following the removal of inorganic carbon by contact with $\mathrm{HCl}$ vapour in a desiccator. The analysis of nitrogen mineralization by microflora was based on the extraction of a $5 \mathrm{~g}$ sludge sample from $50 \mathrm{~cm}^{3}$ of water. The sample was shaken for $30 \mathrm{~min}$ and then centrifuged before the concentration of the following compounds was determined: ammonium-nitrogen (PN-ISO 5664), using a UDK 132 Semiautomatic Distillation Unit VELP, nitrate-nitrogen (PN-C-04576 -08:1982), nitrite-nitrogen (PN-EN 26777:1999), and phosphate-phosphorus (PN-EN ISO 6878:2005). 
Odour sampling and analysis were performed using the dynamic dilution method, that is by changing the flow rate of air through the device for air sampling from area sources (Fig. 2) and by using a vacuum sampling device to keep the flow conditions constant. This made it possible to ascribe a volume flow to the concentration of an odorous substance that was being measured. In addition, $n$-butanol solutions were used to estimate the intensity of odour [11].

Averages and standard deviations were calculated using the Statistica software, developed by Statsoft, Poland. The statistical significance of the odour emission factor was tested with a $t$-test, the Shapiro-Wilk test, and the Brown and Forsythe test, using the Statistica software, developed by Statsoft, Poland.

\section{RESULTS AND DISCUSSION}

The sludge before the treatment (test 1 and 2) had dry matter content (dm) of 13.9-14.3\%, which is relatively low (Table 1 ). The values recommended for conducting a composting process should be within the range of $30-50 \%$ because high moisture content leads to a smaller free air space that is disadvantageous for the oxygen supply. Organic compounds represented $77.7-77.8 \%$ of dry matter content, while total nitrogen and total organic carbon accounted for $6.8-7.8 \% \mathrm{dm}$ and $37-41.9 \% \mathrm{dm}$, respectively. Because of the decreased carbon concentration, the $\mathrm{C} / \mathrm{N}$ ratio was as low as 5.5. Only the sludge with a bark compost addition of up to $20.3 \%$ (test 3 ) was characterised by a considerably higher content of dry matter and organic compounds. In test $4, \mathrm{CaO}$ was added in such an amount that the $\mathrm{pH}$ in this case was a little higher, at 7.5.

Because of the low $\mathrm{C} / \mathrm{N}$ value, there was not any thermophilic phase during the treatment. The temperature inside the sludge was also relatively low, not exceeding $25^{\circ} \mathrm{C}$. During the whole experiment, the largest reduction in volume and total mass was noted in test $2(\mathrm{EM})$, with a decrease of 67 and $78 \%$ respectively. Total mass decreased by $69 \%$ in test 3 (EM + compost) and by $46 \%$ in test 1 .

Changes in organic dry matter content during the experiment were similar for all tests, namely there was a slow decline to $64-67 \%$. At the same time, significant differences in dry matter content were present, with test 1 producing the lowest dry matter content at the end.

Dry matter content in test 2 increased to reach $27.4 \%$ on day 117 . In test 3 , the values were significantly higher when compared to other tests throughout the experiment, varying between 25-38\%. A higher dry matter content was the result of a greater permeability of the sludge and a higher dewatering capacity.

During test 3, a steady acidification of the reaction was observed, ultimately to $\mathrm{pH}$ 5.5. It is at $\mathrm{pH} 5-6$ that most nutrients are maximally available to plants, with growth being most favoured. A similarly low $\mathrm{pH}$ was reported by Himanen and Hänninen [12] in relation to the composting of aerobic and anaerobic sludge. Fang [13] reported lower 
$\mathrm{pH}$ values (within the $\mathrm{pH}$ range of 6-7) after 100 days of composting sewage sludge with coal ash residue. In other tests, there was a slow increase in $\mathrm{pH}$, to neutral or slightly alkaline, reflecting rather a typical change that accompanies the process.

Table 1

The results of sludge processing

\begin{tabular}{|c|c|c|c|c|c|}
\hline \multicolumn{2}{|l|}{ Parameter } & $\begin{array}{c}\text { Test } 1 \\
\text { Control }\end{array}$ & $\begin{array}{c}\text { Test } 2 \\
\text { EM }\end{array}$ & $\begin{array}{c}\text { Test } 3 \\
\text { EM + compost }\end{array}$ & $\begin{array}{c}\text { Test } 4 \\
\mathrm{EM}+\mathrm{CaO}\end{array}$ \\
\hline \multirow{3}{*}{ Volume } & initial, $\mathrm{dm}^{3}$ & 172.8 & 177.6 & 172.8 & 182.4 \\
\hline & final, $\mathrm{dm}^{3}$ & 68.8 & 59.2 & 78.4 & 74.9 \\
\hline & reduction, $\%$ & 60.2 & 66.6 & 54.6 & 58.9 \\
\hline \multirow{3}{*}{ Total mass } & initial, $\mathrm{kg}$ & 101.8 & 125.0 & 137.7 & 128.2 \\
\hline & final, $\mathrm{kg}$ & 55.4 & 27.1 & 42.9 & 57.1 \\
\hline & reduction, $\%$ & 45.6 & 78.3 & 68.8 & 55.6 \\
\hline \multirow{2}{*}{ Dry matter content } & initial, $\%$ & 13.9 & 14.3 & 30.2 & 14.5 \\
\hline & final, $\%$ & 14.8 & 27.4 & 34.7 & 20.1 \\
\hline \multirow{2}{*}{ Organic dry matter content } & initial, \% dmc & 77.8 & 77.7 & 85.1 & 76.7 \\
\hline & final, $\% \mathrm{dmc}$ & 66.5 & 65.6 & 66.9 & 63.7 \\
\hline \multirow{3}{*}{ Total dry matter } & initial, kg & 14.1 & 17.9 & 41.6 & 18.6 \\
\hline & final, $\mathrm{kg}$ & 8.2 & 7.4 & 14.9 & 11.5 \\
\hline & reduction, $\%$ & 42.0 & 58.5 & 64.2 & 38.3 \\
\hline \multirow{3}{*}{ Total organic dry matter } & initial, $\mathrm{kg}$ & 11.0 & 13.9 & 35.4 & 14.3 \\
\hline & final, $\mathrm{kg}$ & 5.4 & 4.9 & 10.0 & 7.3 \\
\hline & reduction, $\%$ & 50.5 & 65.0 & 71.9 & 48.7 \\
\hline \multirow{2}{*}{ Reaction } & initial, $\mathrm{pH}$ & 7.1 & 7.1 & 7.0 & 7.5 \\
\hline & final, $\mathrm{pH}$ & 7.9 & 7.4 & 5.5 & 8.1 \\
\hline \multirow{3}{*}{ Total nitrogen } & initial, \% dmc & 6.8 & 7.8 & 6.6 & 7.1 \\
\hline & final, $\% \mathrm{dmc}$ & 3.7 & 5.6 & 4.2 & 3.3 \\
\hline & reduction, $\%$ & 45.5 & 28.1 & 35.4 & 53.9 \\
\hline \multirow{3}{*}{ Total organic carbon } & initial, \% dmc & 37.3 & 41.9 & 36.2 & 40.3 \\
\hline & final, $\% \mathrm{dmc}$ & 31.1 & 28.4 & 28.9 & 29.0 \\
\hline & reduction, \%] & 16.6 & 32.4 & 20.3 & 28.0 \\
\hline \multirow{2}{*}{$\begin{array}{l}\text { Redox potential } \\
(4 \mathrm{~cm} \text { depth })\end{array}$} & initial, mV] & -127.2 & -94.0 & -175.9 & -176.7 \\
\hline & final, $\mathrm{mV}]$ & -235.6 & 238.4 & 108.1 & -213.6 \\
\hline
\end{tabular}

Visible differences were also noted for the redox potential, measured in situ at a depth of $4 \mathrm{~cm}$ (Fig. 3). In tests 1 and 2, the potential gradually decreased from -19 and $-39 \mathrm{mV}$ (day 4) to -210 and $-246 \mathrm{mV}$ (day 61). Over the same period, the redox potential for test 3 increased to $285 \mathrm{mV}$, while that for test 4 changed from -177 to $-85 \mathrm{mV}$.

The transformation of nitrogen is rather a complicated process, depending simultaneously on many factors such as $\mathrm{pH}$, temperature, and the $\mathrm{C} / \mathrm{N}$ ratio [14]. The analysis of nitrogen mineralisation by microflora showed that in test, the concentration of ammonium nitrogen extracted from the sludge (Fig. 4) slowly decreased during the first 
month of the process from 6.5 to $4.1 \mathrm{~g} \mathrm{NH}_{4}^{+}-\mathrm{N} / \mathrm{kg} \mathrm{dm}$, only to re-increase with an ongoing ammonification to the value of $7.1 \mathrm{~g}$. Similarly, Himanen and Hänninen [12] reported that composted anaerobic sludge had an initial concentration of soluble as high as $8.5 \mathrm{~g} / \mathrm{kg} \mathrm{dm}$, that declined by half between weeks 1 and 2 due to gaseous ammonia stripping.

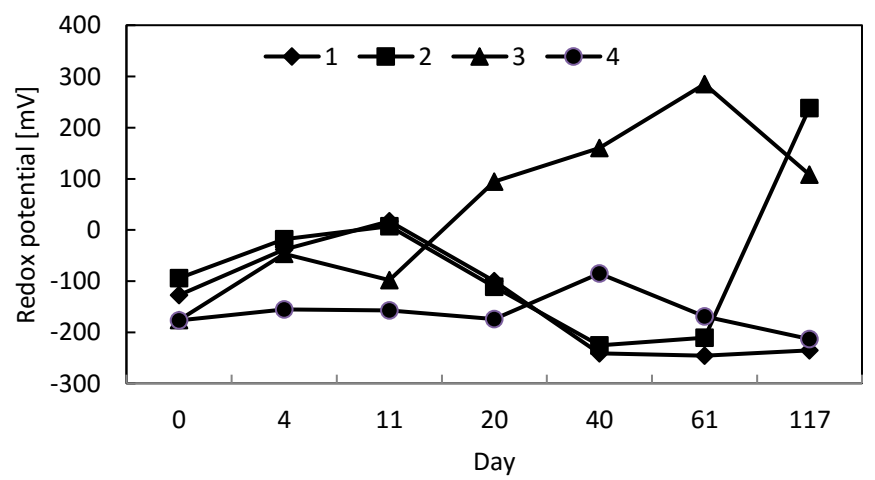

Fig. 3. Redox potential of sludge during the experiment at the depth of $4 \mathrm{~cm}$ :

1 - control test, $2-\mathrm{EM}, 3-\mathrm{EM}+$ compost, $4-\mathrm{EM}+\mathrm{CaO}$

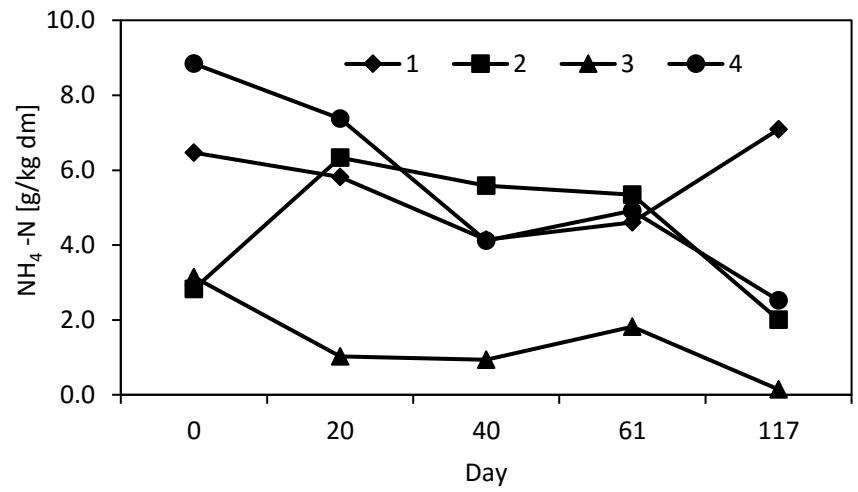

Fig. 4. Ammonia nitrogen extracted from the sludge during the experiment: $1-$ control test, $2-\mathrm{EM}, 3-\mathrm{EM}+$ compost, $4-\mathrm{EM}+\mathrm{CaO}$

The concentration of ammonium ion in test 2 was only about half as high as in test 1 at the beginning of the experiment but it increased by day 20 to $6.3 \mathrm{~g} \mathrm{NH}_{4}^{+}-\mathrm{N} / \mathrm{kg} \mathrm{dm}$, only to keep gradually decreasing up to day 61. A significant decrease in the values of this parameter was noted at the end of the treatment. In contrast, a low concentration of ammonium-nitrogen was noted for the whole process in test 3 (EM + compost), with 
values within the range 0.2 to $1.8 \mathrm{~g}$. This may reflect a faster metabolism by microorganisms, where the availability of oxygen is greater. It was manifested by a faster decline of $\mathrm{NH}_{4}-\mathrm{N}$, as used extensively by microorganisms in cellular protein synthesis [15].

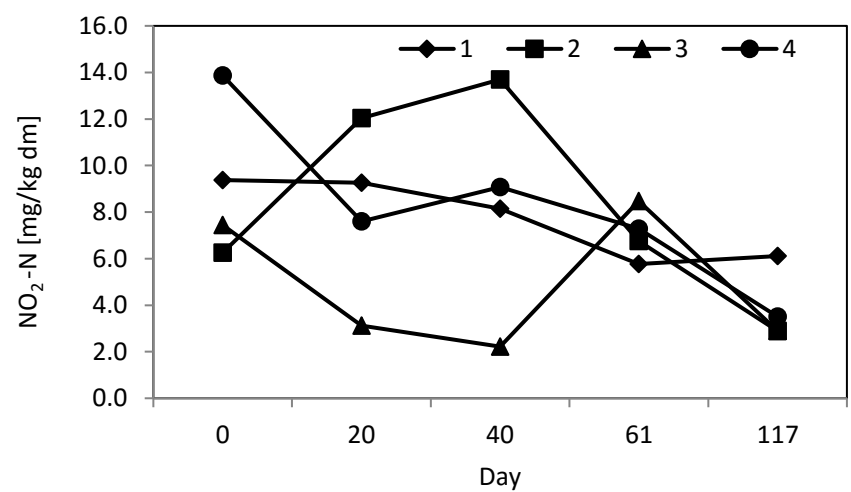

Fig. 5. Nitrite nitrogen extracted from the sludge during the experiment: $1-$ control test, $2-\mathrm{EM}, 3-\mathrm{EM}+$ compost, $4-\mathrm{EM}+\mathrm{CaO}$

Nitrite nitrogen concentrations ranged from 2.2 to $13.9 \mathrm{mg} \mathrm{NO}_{2}^{-}-\mathrm{N} / \mathrm{kg} \mathrm{dm}$ in all tests (Fig. 5). In the control test (1), the nitrate nitrogen content (Fig. 6) declined rapidly from 279.1 to $12.7 \mathrm{mg} \mathrm{NO}_{3}^{-}-\mathrm{N} / \mathrm{kg} \mathrm{dm}$ between days 1 and 20. Next, there was a further decrease to $6.0 \mathrm{mg} \mathrm{NO}-\mathrm{N} / \mathrm{kg} \mathrm{dm}$ by day 61 . The test with $\mathrm{EM} \mathrm{(2)} \mathrm{had} \mathrm{higher} \mathrm{levels} \mathrm{of} \mathrm{nitrate}$ (516 $\mathrm{mg} \mathrm{NO}_{3}^{-}-\mathrm{N} / \mathrm{kg} \mathrm{dm}$ ) at the outset as compared with about 15-20 $\mathrm{mg} \mathrm{NO}_{3}^{-}-\mathrm{N} / \mathrm{kg} \mathrm{dm}$ later, followed by a further decrease to $5 \mathrm{mg} \mathrm{NO}_{3}^{-}-\mathrm{N} / \mathrm{kg} \mathrm{dm}$ at the end of the experiment. The test with $\mathrm{EM}+\mathrm{CaO}$ (4) had small differences as compared with test 1 . A sharp decrease in $\mathrm{NO}_{3}^{-}-\mathrm{N}$ concentration observed at the beginning of the experiment can be attributed to the microbial denitrification in some isolated sludge zones that became anaerobic, to $\mathrm{NO}, \mathrm{N}_{2} \mathrm{O}$, and $\mathrm{N}_{2}$, as a result of which, an alternative pathway for nitrogen loss appeared [16, 17]. Nitrification also took place in test 3. A significant increase in the value of nitrate-nitrogen content at the end of the process (to $120 \mathrm{mg}$ $\mathrm{NO}_{3}^{-}-\mathrm{N} / \mathrm{kg} \mathrm{dm}$ ) was observed, although this constituted only one tenth as much as reported by Himanen and Hänninen [12] for the anaerobic sludge. Test 3 recorded higher final values of the $\mathrm{NO}_{3}^{-} / \mathrm{NH}_{4}^{+}$ratio, implying that the addition of the structural material ensured good aeration conditions [16].

During the experiment, the amount of total nitrogen in tests 1 and 4 was within the range of $4-7.1 \% \mathrm{dm}$, decreasing significantly at the end to approx. $3.5 \% \mathrm{dm}$. In the case of test 3 , it continued to decline (from 6.6 to $2.7 \% \mathrm{dm}$ ) until day 61 . A lower nitrogen concentration reflects more effective mineralisation of nitrogen and the transformation to ammonia, as well as a further transformation to nitrate, in the test with EM and the 
structural material. Between days 61 and 117, the nitrogen concentration in test 3 increased to $4.2 \% \mathrm{dm}$. A similar increase was observed at the end of the experiment in test 2 . In composting, a rise in the total nitrogen level is observed during the maturation phase and may possibly be due to a concentration effect, caused by a strong degradation of labile organic carbon compounds, that reduces the weight of a composting material $[12,14]$.

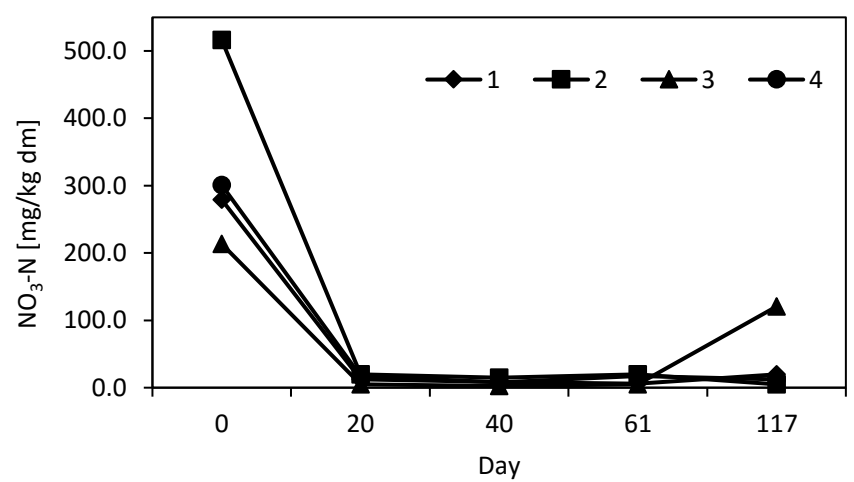

Fig. 6. Nitrate nitrogen extracted from the sludge during the experiment: $1-$ control test, $2-\mathrm{EM}, 3-\mathrm{EM}+$ compost, $4-\mathrm{EM}+\mathrm{CaO}$

A decrease in the concentration of organic carbon also occurred during the experiment. In test 1 , the decrease in organic carbon was from $37.3 \%$ to $31.1 \%$, while in test 2 (EM), it was from $41.9 \%$ to $28.4 \%$. In test 3 (EM + compost), the total concentration of organic carbon decreased from $36.2 \%$ to $28.9 \%$, while in test $4(\mathrm{EM}+\mathrm{CaO})$, from $40.3 \%$ to $29.0 \%$. Along with the loss of nitrogen and a decrease in the levels of organic carbon, the $\mathrm{C} / \mathrm{N}$ ratio in test 1 significantly increased during the treatment, reaching 8.4. Similar changes occurred in tests 4 and 2 but in test 2, a slight decrease was noted by the end of the experiment, with the value of 5.1. The $\mathrm{C} / \mathrm{N}$ ratio in test 3 increased to 10.9 before the nitrogen losses at the end of the experiment caused the decrease of this value to 6.8.

The concentration of phosphate phosphorus extracted from the sludge varied from 0.1 to $0.7 \mathrm{~g} \mathrm{PO}_{4}^{3-}-\mathrm{P} / \mathrm{kg} \mathrm{dm}$ and did not show any direct relationship with either the sludge processing method or the passage of time (Fig. 7).

Odour measurements showed that over the course of the whole experiment, the odour emission factor was about 20-26\% lower in test 2 than in test 1 (Fig. 8). The factor was in turn 3.5 times greater in test 3 than in test 1 at the beginning of the experiment. However, in the same test, a rapid decrease in the noxiousness of odours occurred, such that by day 20 , the value was $79 \%$ lower than that in test 1 . The very low value of the factor was maintained until the end of the experiment. Test 4 had the highest odour emission factor at the outset but during the course of the experiment, the value started to change and was eventually smaller than in test 2 by $20-26 \%$, and test 1 by 
$36-46 \%$. Statistical analysis of the results showed that there is a significant difference between test 3 and other tests (Table 2).

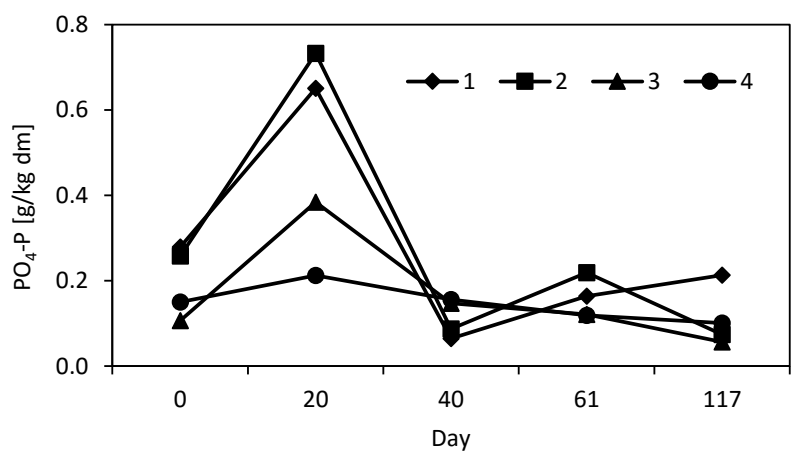

Fig. 7. Phosphate phosphorus extracted from the sludge during the experiment: $1-$ control test, $2-\mathrm{EM}, 3-\mathrm{EM}+$ compost, $4-\mathrm{EM}+\mathrm{CaO}$

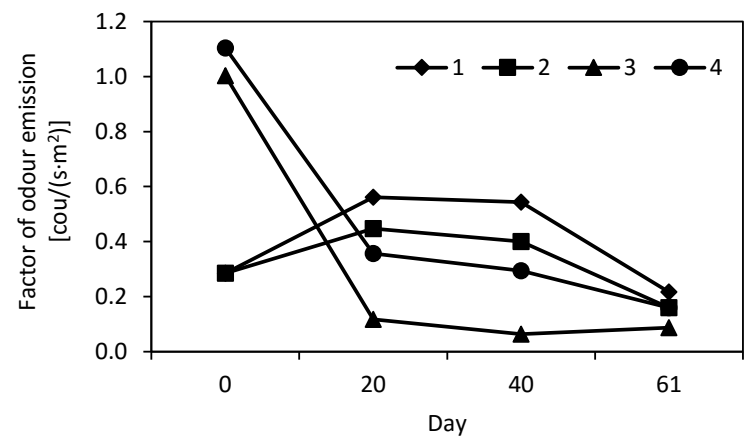

Fig. 8. Odour emission factor during the experiment:

$1-$ control test, $2-\mathrm{EM}, 3-\mathrm{EM}+$ compost, $4-\mathrm{EM}+\mathrm{CaO}$

Table 2

Statistical analysis of the odour emission factor ${ }^{\mathrm{a}}$

\begin{tabular}{|c|c|c|c|c|c|c|c|c|c|}
\hline \multirow{2}{*}{ Test symbol } & \multicolumn{2}{|c|}{ Test $t$} & \multicolumn{2}{|c|}{ Brown and Forsythe test } & \multirow{2}{*}{ Standard deviation } & \multicolumn{2}{|c|}{ Average } \\
\cline { 3 - 10 } & $t$ & $p$ & $F(1, d f)$ & $p$ & & & & \\
\hline 1 & $\mathbf{3}$ & 3.107 & $\mathbf{0 . 0 3 6}$ & 0.826 & 0.415 & 0.194 & 0.027 & 0.440 & 0.089 \\
\hline 4 & $\mathbf{3}$ & 3.003 & $\mathbf{0 . 0 3 9}$ & 1.431 & 0.298 & 0.101 & 0.027 & 0.270 & 0.089 \\
\hline 2 & $\mathbf{3}$ & 2.724 & $\mathbf{0 . 0 5 2}$ & 1.109 & 0.352 & 0.155 & 0.027 & 0.335 & 0.089 \\
\hline 1 & 4 & 1.347 & 0.249 & 0.187 & 0.688 & 0.194 & 0.101 & 0.440 & 0.270 \\
\hline 1 & 2 & 0.731 & 0.505 & 0.0210 & 0.892 & 0.194 & 0.154 & 0.440 & 0.336 \\
\hline
\end{tabular}

aShapiro-Wilk test: $W=0.92, p=0.31$.

Results marked in bold have statistically significant differences. 
The ammonia emission factor at the beginning of the experiment was the lowest for test 1 , at $0.0015 \mu \mathrm{g} /\left(\mathrm{m}^{2} \cdot \mathrm{s}\right)$ (Fig. 9). In the case of other tests, the value was higher by ca. $100 \%$. The test with EM (test 2) had the longest period of increasing (up to day 40), with the highest level of ammonia emission at $2.9 \mu \mathrm{g} / \mathrm{m}^{2} \mathrm{~s}$ on day 40 . EM added to test 2 produced an increased and prolonged ammonia emission. Test with EM + compost (3) had the lowest emissions, which did not exceed $0.05 \mu \mathrm{g} / \mathrm{m}^{2} \mathrm{~s}$, with a maximum value on day 20. A similar duration of ammonia emissions was observed by Himanen and Hänninen [12]. Such a lower emission in comparison to test 2 was caused by adding bark compost to the sewage sludge. Also Dach [15] stated that organic components added to the composted sewage sludge exert a great impact on the levels of ammonia emission.

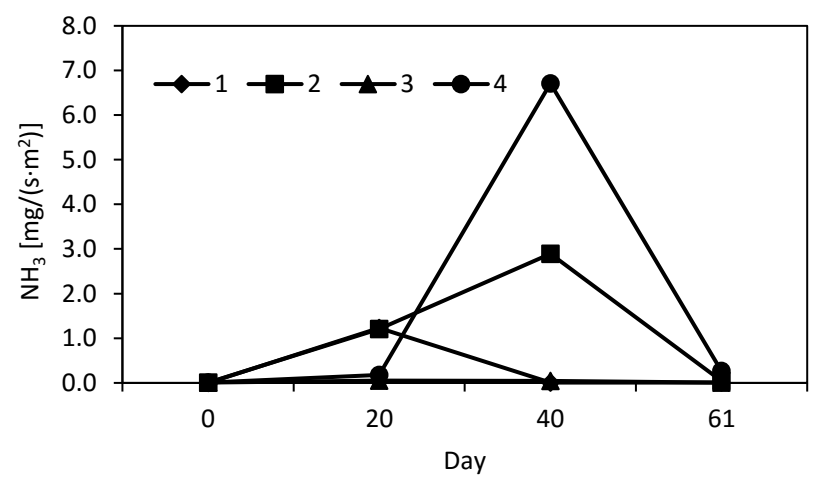

Fig. 9. Ammonia emission factor during the experiment: $1-$ control test, $2-\mathrm{EM}, 3-\mathrm{EM}+$ compost, $4-\mathrm{EM}+\mathrm{CaO}$

The final results show that the treatment of sludge with the EM biopreparation and the structural material on a semi-industrial scale proceeded in a similar manner to the laboratory scale process, involving the addition of wood chips [9]. The bark compost addition also increased the initial dry matter content, as well as altered the structure of the sludge, making it porous, and ensured a high redox potential from day 40 of the process. However, the semi industrial scale trial differed from the laboratory scale process in that the increased nitrate nitrogen production was observed much later - on day 117 , as opposed to day 30 in laboratory tests. What is more, the concentrations of ammonium nitrogen were significantly higher in this study than in the laboratory tests.

In contrast to our findings, Vliet [17] found that the addition of an effective microorganism mixture to the slurry manure composted on the laboratory scale had no measurable effect on the bacterial diversity and chemical composition of the manure, as well as on the grass production. Likewise, Dach [18] stated that use of the EM preparations did not yield any clear positive effect when it came to sludge composting and even resulted in a slight decrease in the dynamics of the process. However, the composting 
material had a higher $\mathrm{C} / \mathrm{N}$, which equalled 15 , and there was a thermophilic phase during the treatment.

\section{CONCLUSIONS}

The processing of the sludge with added effective microorganisms (EM) caused a 20-26\% reduction in odour emissions despite an increase in ammonia emissions. It also led to a higher dry matter content which indicates a better dewatering ability of the sludge treated with EM.

The treatment of the sludge with EM and bark compost resulted in the highest dry matter content and the lowest odour emission. Bark compost addition enhanced the effectiveness of the sludge processing and limited the emission of odour.

During testing on a semi-industrial scale, as opposed to the laboratory experiments, the concentrations of ammonia were significantly higher and the nitrate nitrogen production had a later onset. It could be caused by a higher share of anaerobic processes in experiments conducted on a semi-industrial scale.

The treatment of wastewater sludge with EM and the structural material when the $\mathrm{C} / \mathrm{N}$ ratio is low can help achieve the desired goal of reducing the odour emission.

\section{ACKNOWLEDGMENT}

The study received funds for scientific research from the Polish Ministry of Science and Higher Education as a part of the project No. PBZ-MEiN-5/2/2006.

\section{REFERENCES}

[1] Gostelow P., PARsons S.A., StuEtz R.M., Odour measurements for sewage treatment works, Water Res., 2001, 35 (3), 579.

[2] Kim H., Murthy S., McConnell L.L., Peot C., Ramirez M., Strawn M., Characterization of wastewater and solids odors using solid phase microextraction at a large wastewater treatment plant, Water Sci. Technol., 2002, 46 (10), 9.

[3] SERCOMBE D.C.W., The control of septicity and odours in sewerage systems and at sewage treatment works operated by Anglian Water Services Limited, Water Sci. Technol., 1995, 31 (7), 283.

[4] STUETZ R.M., FENNER R.A., ENGIN G., Assessment of odours from sewage treatment works by an electronic nose, $\mathrm{H}_{2} \mathrm{~S}$ analysis and olfactometry, Water Res., 1999, 33 (2), 453.

[5] HIROsHI E., Adding of Actinomycetes seed on high rate composting and odor suppression during garbage composting, J. Biosci. Bioeng., 2001, 91 (6), 607.

[6] Sun Y.H., LuO Y.M., Wu L.H., Li Z.G., SONG J., CHRISTIE P., Survival of faecal coliforms and hygiene risks in soils treated with municipal sewage sludges, Environ. Geochem. Hlth., 2006, 28 (1-2), 97.

[7] SHABAn A.M., Bacteriological evaluation of composting systems in sludge treatment, Water Sci. Technol., 1999, 40 (7), 165.

[8] Higa T., Microbiological Method for Disposing of Organic Waste Materials, United States Patent, 1998, No. 5707856. 
[9] Grabas M., Czerwieniec E., Tomaszek J.A., MasŁoń A., LeszczyńsKa J., Effectiveness of sludge processing with biopreparation (EM-bio) and structural material, Environ. Prot. Eng., 2009, 35 (2), 131.

[10] Grabas M., Tomaszek J.A., CZerwienieC E., Zamorska J., KukuŁa E., MasŁoń A., GruCa-Rokosz R., Noxiousness of odours and properties of wastewater sludge processing with EM biopreparation, Environ. Prot. Eng., 2011, 37 (3), 17.

[11] KoŚmider J., MAZur-ChrZanowska B., Wyszyński B., Odours, PWN, Warsaw 2002 (in Polish).

[12] Himanen M., HÄNNINEN K., Composting of bio-waste, aerobic and anaerobic sludges. Effect of feedstock on the process and quality of compost, Biores. Technol., 2011, 102, 2842.

[13] FAng M., Wong J.W.C., Ma K.K., Wong M.H., Co-composting of sewage sludge and coal fly ash: nutrient transformations, Biores. Technol., 1999, 67, 19.

[14] Bernal M.P., AlburquerQue J.A., Moral R., Composting of animal manures and chemical criteria for compost maturity assessment. A review, Biores. Technol., 2009, 100, 5444.

[15] Dach J., Niżewski P., CZeKala J., ZвYtek Z., Comparison of ammonia emission from composted swine farmyard manure and composted sewage sludge, J. Res. Appl. Agric. Engng, 2008, 53 (1), 58 (in Polish).

[16] Cofie O., Kone D., Rothenberger S., Moser D., Zubruegg C., Co-composting of faecal sludge and organic solid waste for agriculture. Process dynamics, Water Res., 2009, 43, 4665.

[17] Van Vliet P.C.J., Bloem J., De Goede R.G.M., Microbial diversity, nitrogen loss and grass production after addition of effective micro-organisms (EM) to slurry manure, Appl. Soil. Ecol., 2006, 32, 188.

[18] DACh J., Wolna-MarUwKa A., ZBYteK Z., Influence of effective microorganisms addition (EM) on composting process and gaseous emission intensity, J. Res. Appl. Agric. Engng, 2009, 54 (3), 49 (in Polish). 